ISSUES IN MEDICINE

\title{
The burden of infertility among HIV-positive couples in South Africa: The available evidence
}

\author{
D Basu, J K Basu, G T H Ellison
}

Most of the 5 million HIV-positive South Africans are in the reproductive age group. The current infertility rate in this group is $15-20 \%,{ }^{1}$ and it is likely that a substantial proportion of offspring are HIV positive. Given the implementation of highly active antiretroviral therapy (HAART), expectancy and quality of life, including reproductive aspirations, are raised. However, the prevalence of infertility among HIV-positive South Africans remains unknown.

\section{Aim and method}

We wished to determine the burden of infertility among HIVpositive (concordant and discordant) couples in South Africa (SA) so that the issue could be addressed in a safe and costeffective manner. We conducted a systematic search of research evidence on the burden of infertility among HIV-positive couples in SA, that was available on Pubmed and Google Scholar, using the following search string: [HIV OR AIDS] AND [infertil*] AND [males AND females] AND ["South Africa"]. The search also included all non-research evidence on www.google.co.za, www.iol.co.za, www.mg.co.za, and www. news24.com. All articles published in English over the past 10 years were included. Pearl-growing techniques were applied to examine whether any of the references cited in any of the relevant evidence found might also be eligible for inclusion. ${ }^{2}$

\section{Results}

There was no research or non-research evidence on the burden of infertility among HIV-discordant and concordant couples in SA. We identified 10 items of research (2 through pearlgrowing) and 3 items of non-research evidence, respectively; 12 were qualitative studies that focused on the psychosocial aspects of such couples on their fertility intentions. Few studies addressed health care providers' and policy makers' attitudes towards providing fertility services for HIV-positive couples (Table I).

Dr D Basu is a Public Health Medicine specialist in the Department of Community Health affiliated to Charlotte Maxeke Johannesburg Academic Hospital and the University of the Witwatersrand. Dr J Basu is a specialist in the Department of Obstetrics and Gynaecology at the same hospital. Professor G Ellison is director of the Graduate School of London Metropolitan University.

Corresponding author: D Basu (Debashis.Basu@wits.ac.za)
The review identified the following key findings:

- HIV infection results in reduced fertility and poor pregnancy outcomes.

- Reproductive aspirations of HIV-positive couples are subject to individual variation.

- There is a delicate balance between HIV status and reproductive aspirations that is strongly influenced by use of HAART, health status of the individual, provider's attitude, and social and cultural norms.

- The need for provision of fertility treatment to HIV-positive couples will grow.

- The need for risk-reduction fertility treatment for HIV discordant couples is increasing.

- Timed unprotected intercourse is a risky way to achieve conception, while assisted conception (such as sperm washing and intra-uterine insemination) are safe alternatives and may be cost-effective in the long term.

- Health care providers are willing to provide fertility treatment to HIV-positive couples, although there is fear of over-expense and lack of knowledge regarding riskreduction treatment among health care managers.

- Dedicated work is necessary to quantify and address the problem in a safe and cost-effective way.

\section{Discussion and conclusion}

Evidence about the prevalence of infertility among HIVpositive couples in SA is lacking. Additionally, the availability and the uptake of infertility services by HIV-positive couples in SA are unknown. Recent advances in the fertility management of HIV-positive couples are increasingly recognised as being effective in preventing transmission between discordant partners and from mother to fetus. These interventions have been well received by HIV-positive couples in developed countries. $^{3}$ The International Federation of Gynaecology and Obstetrics allows the use of assisted reproductive techniques (ART) for all HIV-positive people in an equitable manner in properly selected cases, and there should not be any discrimination because of HIV status. ${ }^{4}$ Further studies are necessary to determine the relationship between HIV status and infertility and the burden of infertility among HIV-positive people in SA. Since the reproductive rights of all South Africans are enshrined in the Constitution, health services should ensure that HIV-positive couples have access not only to antiretroviral treatment but also to other reproductive health services including fertility. ${ }^{5}$

1. Basu JK. Service, training and research into infertility in public hospitals in South Africa. $S$ Afr Med J 2007; 97(11): 1018.

2. Sclosser RW, Wendt O, Bhavnani S, Nail-Chiwetalu B. Use of information-seeking strategies for developing systematic reviews and engaging in evidence-based practice: the application of 

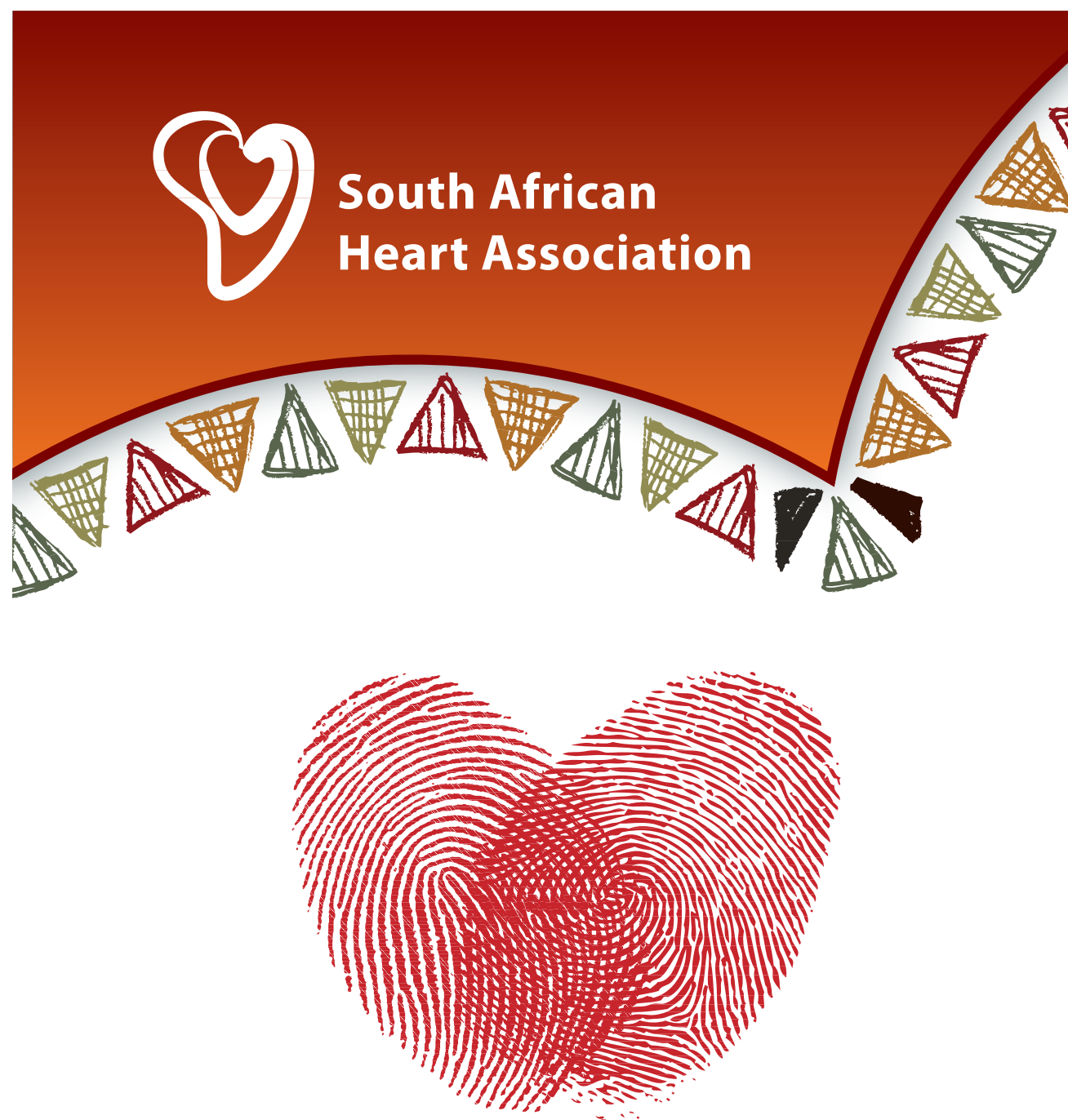

\section{HOLISTIC HEART CARE} SA Heart Association Congress 2010

Clinical \& Interventional Cardiology

Enhancing your day to day care, expanding your horizons

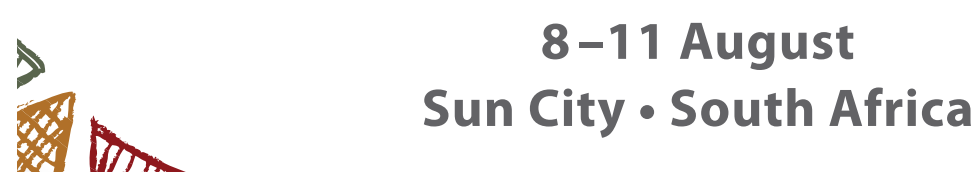

Sun City • South Africa
$\Rightarrow$ National Women's Day Partner's Programme

$\Rightarrow$ Reduced Weekday Accommodation Rates Offered - Take advantage of the Long Weekend!

$P$ Interactive Academic Programme

$\$$ Outstanding Panel of International \& Local Speakers

$\Rightarrow$ Sun City offers an exciting Children's Programme

$\Rightarrow$ Large discounts on early registration

$\Rightarrow$ CPD \& Ethics Points

Sunday 8 August:

Full Day Mayo Clinic Echocardiography Workshop

For further information contact the Congress Office:

Sue McGuinness Communications \& Event Management

PO Box 782243 , Sandton, 2146, South Africa

Telephone: +27 (0)11 4473876 • Fax: +27 (0)11 4428094

Email: suemc@icon.co.za

\section{www.saheart.co.za}




\section{FORUM}

\section{Table I. List of research and non-research evidences}

\begin{tabular}{|c|c|c|}
\hline Type & Source & Reference \\
\hline Research & Pubmed & $\begin{array}{l}\text { Chigumadzi PT, Moodley J, Bagratee. Infertility profile at King Edward VIII Hospital, Durban, } \\
\text { South Africa. Trop Doct 1998; 28: 168-172. }\end{array}$ \\
\hline Research & Pubmed & $\begin{array}{l}\text { Cooper D, Bracken H, Myer L, et al. Reproductive intentions and choices among HIV-infected } \\
\text { individuals in Cape Town, South Africa: Lessons for reproductive policy and service provision from a } \\
\text { qualitative study. New York: Population Council, September } 2005 .\end{array}$ \\
\hline Research & Pubmed & Gray GE, McIntyre JA. Effect of HIV on women. AIDS Read 2006; 16: 365-368, 373-377. \\
\hline Research & Pubmed & $\begin{array}{l}\text { Mohohlo M, Khosa T, Mohapi L, Gray G. Pregnancy related events in an anti-retroviral program. } \\
\text { PEPFAR implementers meeting. Abstract 113. } 2006 .\end{array}$ \\
\hline Research & Pubmed & $\begin{array}{l}\text { Nosarka S, Hoogendijk CF, Siebert TJ, Kruger TF. Assisted reproduction in the HIV-serodiscordant } \\
\text { couple. S Afr Med J 2007; 97(1): 24-26. }\end{array}$ \\
\hline Research & Pubmed & $\begin{array}{l}\text { Harries J, Cooper D, Myer L, Bracken H, Zweigenthal V, Orner P. Policy maker and health care } \\
\text { provider perspectives on reproductive-decision making amongst HIV-infected individuals in } \\
\text { South Africa. BMC Public Health 2007; 7: } 282 \text {. }\end{array}$ \\
\hline Research & Pubmed & $\begin{array}{l}\text { Cooper D, Harries J, Myer L, Orner P, Bracken H, Zweigenthal V. 'Life is still going on': } \\
\text { Reproductive intentions among HIV-positive women and men in South Africa. Soc Sci Med 2007; } \\
65(2): 274-283 \text {. }\end{array}$ \\
\hline Research & Pubmed & $\begin{array}{l}\text { Myer L, Morroni C, Rebe K. Prevalence and determinants of fertility intentions of HIV-infected } \\
\text { women and men receiving antiretroviral therapy in South Africa. AIDS Patient Care and STDs } \\
\text { 2007; 21(4): 278-285. }\end{array}$ \\
\hline Research & Pubmed & $\begin{array}{l}\text { Nduna M, Farlane L. Women living with HIV in South Africa and their concerns about fertility. } \\
\text { AIDS Behav 2009; 13: S62-S65. }\end{array}$ \\
\hline Research & Pubmed & $\begin{array}{l}\text { Cooper D, Moodley J, Zweigenthal V, Bekker LG, Shah I, Myer L. Fertility intentions and } \\
\text { reproductive health care needs of people living with HIV in Cape Town, South Africa: } \\
\text { Implications for integrating reproductive health and HIV care services. AIDS Behav 2009; } \\
\text { 13(Suppl) 1: 38-46. }\end{array}$ \\
\hline Non-research & www.iol.co.za & $\begin{array}{l}\text { Dyer SJ. Infertility in African countries: challenges created by the HIV epidemic http:/ / } \\
\text { eshremonographs.oxfordjournals.org/cgi/reprint/2008/1/48 (accessed } 30 \text { June 2008). }\end{array}$ \\
\hline Non-research & www.iol.co.za & $\begin{array}{l}\text { Hirschler B. Doctors seek IVF for Africa's infertile. http:/ / www.thestar.co.za/index. } \\
\text { php?fArticleId=4174630 (accessed } 30 \text { June 2008). }\end{array}$ \\
\hline Non-research & www.google.co.za & $\begin{array}{l}\text { Cooper D. In pursuit of social development goals and HIV-infected women's reproductive rights } \\
\text { - South Africa as a case study. Agenda 2008; 1(1): 4-15. http:/ / www.agenda.org.za/content/blogca } \\
\text { tegory/88888970/88889086/ (accessed } 30 \text { June 2008). }\end{array}$ \\
\hline
\end{tabular}

traditional and comprehensive pearl growing. A review. Int J Lang Commun Disord 2006; 41(5): 567-582.

3. Sunderam S, Hollander L, Macaluso M, et al. Safe conception for HIV discordant couples through sperm-washing: experience and perceptions of patients in Milan, Italy. Reprod Health Matters 2008: 16(31): 211-219.
4. FIGO. Ethical Issues in Obstetrics and Gynaecology for the Study of Ethical Aspects of Human Reproduction and Women's Health. London: FIGO, October 2009: 62-63.

5. Delvaux T, Nostlinger C. Reproductive choice for women and men living with HIV: contraception, abortion and fertility Reprod Health Matters 2007; 15(29 suppl): 46-66. 